\title{
Comparison of cholesterol levels among lipoprotein fractions separated by anion-exchange high-performance liquid chromatography in periparturient Holstein-Friesian dairy cows
}

\author{
Tomoya TAKAHASHI ${ }^{1,2)}$, Akihiro MORI ${ }^{1) *}$, Hitomi ODA ${ }^{1)}$, Isao MURAYAMA ${ }^{3)}$, \\ Mitsuhiko KOUNO ${ }^{3)}$ and Toshinori SAKO ${ }^{2)}$ \\ ${ }^{1)}$ School of Veterinary Nursing \& Technology, Faculty of Veterinary Science, \\ Nippon Veterinary and Life Science University, 1-7-1 Kyonancho, Musashino, Tokyo 180-8602, Japan \\ ${ }^{2)}$ Kenhoku Veterinary Clinical Center, Miyagi Prefectural Agricultural Mutual Aid Association, 1-3-1 Nakae, \\ Sanuma, Hasamacho, Tome, Miyagi 987-0511, Japan \\ ${ }^{3)}$ Kennan Veterinary Clinical Center, Miyagi Prefectural Agricultural Mutual Aid Association, 10 Sakuraokamae, \\ Hukuokahukaya, Shiroishi, Miyagi 989-0731, Japan
}

J. Vet. Med. Sci.

83(2): 260-266, 2021

doi: 10.1292/jvms.20-0361

Received: 12 June 2020

Accepted: 27 November 2020 Advanced Epub:

7 December 2020
ABSTRACT. Changes in lipoprotein profiles occur in dairy cows during the periparturient period and in cows with transition cow disease. Here, the lipoprotein profiles of Holstein-Friesian dairy cows during the periparturient period were obtained by anion-exchange, high-performance liquid chromatography to evaluate the usefulness of lipoprotein profile evaluation during the periparturient period and in cows with fatty liver and milk fever. Lipoprotein levels (including total and high- (HDL-C) and low-density lipoprotein (LDL-C) cholesterol) in 10 healthy cows were low 4 weeks prepartum, with the lowest values at calving or within 1 week of calving; the values increased at 8 weeks postpartum. The lipoprotein levels were measured in 16 cows diagnosed with fatty liver $(n=10)$ or milk fever $(n=6)$ and compared to 10 healthy dairy cows. A significant difference was observed in HDL-C between healthy cows (at calving and 1 week postpartum), and the fatty liver and milk fever cows. Cows with fatty liver and milk fever had a lower mean $\mathrm{HDL}-\mathrm{C}$ than the 10 healthy dairy cows at calving and 1 week postpartum. $\mathrm{HDL}-\mathrm{C}$ might be a good indicator of energy balance for differentiating healthy cows from those with transition cow disease.

KEY WORDS: dairy cow, lipoprotein profile, periparturient period, transition cow disease

Lipid metabolism in dairy cows changes considerably during the periparturient period $[7,12,13]$. The transition period is 3 weeks before and after calving, and it is frequently fraught with metabolic disorders as the cows adjust to the birth event and lactation [1]. Dairy cows frequently achieve negative energy balance at this time, which is associated with an increase in milk production and a decrease in dry matter intake (DMI) enforced by fetal growth $[14,15]$. Non-esterified fatty acids (NEFAs) mobilized from adipose tissue are transported to the liver under negative energy balance. They are either oxidized or esterified into triglycerides (TGs) in hepatic cells [3]. Re-esterification of TGs leads to fat accumulation in the liver (fatty liver) [10]. This pathophysiology typically causes liver function disturbance, perinatal disease, and poor fertility [2, 4, 24, 28]. During lactation, lipid metabolism is activated in dairy cows to ensure energy for milk yield. Furthermore, the serum level of sex steroid hormones that are synthesized from cholesterol (such as estrogen and progesterone) changes dramatically during the periparturient period [25].

The changes in lipid metabolism after calving might lead to abnormal cholesterol metabolism. Therefore, it is important to examine the changes in cholesterol metabolism in dairy cows during the transition period and the difference between healthy cows and those with transition cow disease (TCD). Previously, we reported that anion-exchange (AEX) high-performance liquid chromatography (HPLC) would be a useful method to evaluate cholesterol level in lipoprotein fractions, such as high-density lipoprotein (HDL), low-density lipoprotein (LDL), intermediate-density lipoprotein (IDL), and very low-density lipoprotein (VLDL), in dairy cows and dogs as compared to ultracentrifugation method (only for daily cows) and gel permeation HPLC (for daily cows and dogs) [23, 29]. However, the AEX-HPLC method has not been evaluated in dairy cows during the transition period or in those with TCD. 
The objectives of this study were as follows. First, preliminary study of the changes in cholesterol levels in lipoprotein fractions in 10 healthy dairy cows during the transition period on two farms with a good milk yield performance and reproductive rate were evaluated. Secondly, the lipoprotein profiles of dairy cows with and without TCD (such as fatty liver and milk fever) were compared by AEX-HPLC. Differences in lipoprotein profiles between dairy cows with and without TCD have not been fully evaluated. We hypothesized that some lipoprotein profiles differ between dairy cows with and without TCD and that these parameters might be used as a bovine energy metabolism marker in dairy cows.

\section{MATERIALS AND METHODS}

This study was conducted from January to September 2016. Ten healthy Holstein-Friesian dairy cows in the transition period and 16 Holstein-Friesian dairy cows with TCD (fatty liver, milk fever, and/or displaced abomasum) were used. The profiles of the 10 healthy dairy cows used in this study are shown in Table 1. Of the 10 healthy dairy cows, five were housed on two different farms (Farms A and B) in Miyagi Prefecture. We selected these farms because they had a good milk yield performance and reproductive rate. The profiles of two farm used in this study are shown in Table 2. The profiles of feedstuffs provided on farms A and B are shown in Table 3. Cows on farm A and B were housed in a tie stall and had ad libitum access to water. Sixteen dairy cows with fatty liver, milk fever, and/or displaced abomasum were housed in different dairy farms. The diagnoses of fatty liver, milk fever, and displaced abomasum are detailed as follows: Fatty liver: clinical signs are confirmed as a previous high body condition score (BCS), a rapid decrease in BCS, and ketone body excretion (body odor, milk, and/or urine detection). Furthermore, serum biochemical analysis revealed high aspartate aminotransferase (over $100 \mathrm{IU} / \mathrm{l}$ ), and high T-bilirubin (over $0.5 \mathrm{mg} / \mathrm{dl}$ ). Milk fever: clinical signs were confirmed as a chilled feeling of the skin and ataxia due to muscle relaxation of the whole body. Serum biochemical analysis revealed decreased blood calcium concentration (below $7.4 \mathrm{mg} / \mathrm{dl}$ ). Displaced abomasum: diagnosis was confirmed by a pinging sound of the enlarged abomasum. In the case of a left displacement, this was observed in the 8th intercostal space and paralumbar fossa, one-third down the left flank. In the case of a right displacement, this was observed in the 8th intercostal space and the last rib, in the upper $1 / 2$ of the right flank. Of the 16 cows with fatty liver, milk fever, and/or a displaced abomasum, seven cows were diagnosed as fatty liver, two cows were diagnosed with fatty liver and a displaced abomasum, one cow was diagnosed as having fatty liver and milk fever. These 10 cows were grouped as the fatty liver group. Six cows were diagnosed as having milk fever, and these six cows were designated the milk fever group. Profiles of the 16 cows with transitional disorder are shown in Table 4.

Informed consent was obtained from all farmers after describing the purpose, nature, and potential risks and benefits of the study. Ethics approval for this work was provided by the Nippon Veterinary and Life Science University Animal Research Committee (examination code; 27S-74).

Table 1. Profiles of healthy dairy cows used to assess the lipoprotein fractions

\begin{tabular}{cccccccc}
\hline No & Farm & Breeds & Birth date & Parity & Calving day & $\begin{array}{c}\text { Calving interval } \\
\text { (days) }\end{array}$ & $\begin{array}{c}\text { Annual milk } \\
\text { yield }(\mathrm{kg})\end{array}$ \\
\hline 1 & A & Holstein & $2011 / 3 / 11$ & 3 & $2016 / 2 / 19$ & 500 & 12,177 \\
2 & A & Holstein & $2005 / 1 / 29$ & 9 & $2016 / 3 / 19$ & 503 & 11,753 \\
3 & A & Holstein & $2011 / 7 / 19$ & 4 & $2016 / 3 / 26$ & 362 & 11,983 \\
4 & A & Holstein & $2012 / 7 / 5$ & 3 & $2016 / 5 / 22$ & 342 & 9,705 \\
5 & A & Holstein & $2012 / 6 / 2$ & 3 & $2016 / 7 / 6$ & 371 & 10,797 \\
6 & B & Holstein & $2009 / 9 / 26$ & 5 & $2016 / 3 / 23$ & 393 & 11,213 \\
7 & B & Holstein & $2007 / 9 / 14$ & 7 & $2016 / 3 / 27$ & 475 & 11,925 \\
8 & B & Holstein & $2008 / 10 / 18$ & 6 & $2016 / 4 / 11$ & 552 & 12,153 \\
9 & B & Holstein & $2012 / 1 / 1$ & 3 & $2016 / 4 / 2$ & 469 & 12,261 \\
10 & B & Holstein & $2010 / 8 / 16$ & 3 & $2016 / 3 / 31$ & 555 & 12,925 \\
\hline
\end{tabular}

Table 2. Profiles of two dairy farms used in this study

\begin{tabular}{lrr}
\hline & Farm A & Farm B \\
\hline Milk yield per cow (kg) & 34.1 & 30.3 \\
Milk fat percentage per cow (\%) & 3.89 & 3.75 \\
Milk protein percentage per cow (\%) & 3.41 & 3.22 \\
Fat-free solids per cow (\%) & 8.98 & 8.63 \\
Yearly milk production (kg) for 305 days & 10,763 & 9,462 \\
Average parity counts & 2.2 & 2.7 \\
Calving interval (day) & 399 & 426 \\
Open period (day) & 128 & 168 \\
\hline
\end{tabular}

Values are expressed as averages. 
Table 3. The profiles of feedstuff for Farm A and B

\begin{tabular}{lcccc}
\hline & \multicolumn{2}{c}{ Lactation stage } & \multicolumn{2}{c}{ Dry stage } \\
& Farm A & Farm B & Farm A & Farm B \\
\hline Concentrate (TMR 70.0\%, CP 15.5\%) & 12.6 & 12.0 & 6.0 & 2.0 \\
Timothy hay & 1.0 & 2.0 & 2.0 & 3.0 \\
Oats hay & 2.5 & 2.0 & 2.0 & 3.0 \\
Hay cube & 7.0 & 3.0 & & \\
Beet pulp & 2.5 & 3.0 & 2.0 & 2.0 \\
Italian silage & 0.3 & 6.0 & 5.0 & 6.0 \\
Total & 25.9 & 28.0 & 17.0 & 16.0 \\
\hline
\end{tabular}

Values are expressed as kg. TMR was supplied at 08:00 a.m. and 06:00 p.m. TMR means total mixed ration. $\mathrm{CP}$ means crude protein.

Table 4. Profiles of 16 Holstein cows with transitional disorder

\begin{tabular}{|c|c|c|c|c|c|c|c|c|}
\hline \multirow{2}{*}{ No } & \multirow{2}{*}{ Breed } & \multirow{2}{*}{ Birth date } & \multirow{2}{*}{ Parity } & \multicolumn{2}{|c|}{ Periparturient disease } & \multirow{2}{*}{$\begin{array}{l}\text { Days after } \\
\text { calving }\end{array}$} & \multirow{2}{*}{$\begin{array}{l}\text { Body condition } \\
\text { score }\end{array}$} & \multirow{2}{*}{$\begin{array}{c}\text { Group of } \\
\text { disease }\end{array}$} \\
\hline & & & & main disease & concurrent disease & & & \\
\hline 1 & Holstein & $2011 / 3 / 17$ & 3 & Milk fever & & 0 & 3.25 & Milk fever \\
\hline 2 & Holstein & $2009 / 7 / 8$ & 4 & Fatty liver & Displaced abomasum & 3 & 3.25 & Fatty liver \\
\hline 3 & Holstein & $2010 / 6 / 25$ & 4 & Fatty liver & & 2 & 3.25 & Fatty liver \\
\hline 4 & Holstein & $2010 / 2 / 14$ & 5 & Fatty liver & & 2 & 4.00 & Fatty liver \\
\hline 5 & Holstein & $2010 / 3 / 16$ & 4 & Milk fever & & 1 & 3.50 & Milk fever \\
\hline 6 & Holstein & $2012 / 3 / 7$ & 3 & Fatty liver & Milk fever & 1 & 3.25 & Fatty liver \\
\hline 7 & Holstein & $2010 / 5 / 12$ & 4 & Milk fever & & 1 & 3.50 & Milk fever \\
\hline 8 & Holstein & $2010 / 12 / 10$ & 4 & Milk fever & & 0 & 3.25 & Milk fever \\
\hline 9 & Holstein & $2010 / 9 / 23$ & 4 & Fatty liver & & 7 & 2.50 & Fatty liver \\
\hline 10 & Holstein & $2012 / 9 / 16$ & 3 & Fatty liver & & 9 & 3.00 & Fatty liver \\
\hline 11 & Holstein & $2009 / 12 / 6$ & 3 & Fatty liver & & 1 & 4.50 & Fatty liver \\
\hline 12 & Holstein & $2008 / 4 / 8$ & 4 & Milk fever & & 5 & 2.75 & Milk fever \\
\hline 13 & Holstein & $2010 / 5 / 9$ & 3 & Fatty liver & & 5 & 3.50 & Fatty liver \\
\hline 14 & Holstein & $2010 / 1 / 7$ & 4 & Milk fever & & 1 & 3.50 & Milk fever \\
\hline 15 & Holstein & $2011 / 12 / 4$ & 3 & Fatty liver & Displaced abomasum & 7 & 3.50 & Fatty liver \\
\hline 16 & Holstein & $2012 / 5 / 27$ & 3 & Fatty liver & Displaced abomasum & 7 & 3.50 & Fatty liver \\
\hline
\end{tabular}

Blood samples $(10 \mathrm{ml})$ were obtained from the caudal vein of the cow. To evaluate changes in the lipoprotein fractions and biochemical analysis in healthy dairy cows during the transition period, the following seven sampling times were selected: 4 weeks (w) prepartum, 2 weeks (w) prepartum, 0-1 days after calving date (calving), 1 week (w) postpartum, 2 weeks (w) postpartum, 4 weeks (w) postpartum, and 8 weeks (w) postpartum. Samples from the 10 healthy dairy cows were collected at midmorning for lipoprotein fraction and serum biochemistry tests.

Blood samples from the 16 dairy cows with fatty liver and milk fever group were collected at the first medical examination and evaluated by veterinarians belonging to Miyagi Prefectural Agricultural Mutual Aid Association according to the practice guidelines for livestock. As fatty liver and/or milk fever occurs within $1 \mathrm{w}$ of calving, the lipoprotein profiles of the 16 dairy cows in the fatty liver and milk fever group were compared with those of the 10 healthy dairy cows (at calving and $1 \mathrm{w}$ postpartum) in the two farms previously described. Blood samples were immediately collected in polypropylene tubes and allowed to coagulate at room temperature for $15 \mathrm{~min}$ before centrifugation $\left(1,700 \times g\right.$ for $10 \mathrm{~min}$ at $\left.4^{\circ} \mathrm{C}\right)$ to separate the serum. Serum samples were divided into two polypropylene tubes. One tube with a serum sample was sent to Monolis Inc. (Tokyo, Japan) for AEX-HPLC to measure the HDL cholesterol (HDL-C), LDL cholesterol (LDL-C), IDL cholesterol (IDL-C), and VLDL cholesterol (VLDL-C) levels. HDL-C/LDL-C (\%), HDL-C/total C (Total-C) (\%), and LDL-C/Total-C ratios (\%) were calculated. AEX-HPLC was carried out as previously described [18]. The other tube with a serum sample was sent to Barn Animal Medical Examination Training Institute at Miyagi Prefectural Agricultural Mutual Aid Association for serum biochemistry analyses, including total protein, albumin, total bilirubin, aspartate aminotransferase, $\gamma$-glutamyltransferase, blood urea nitrogen, creatinine, glucose, calcium, TG, inorganic phosphate, magnesium, phospholipid, and NEFAs by photometry (BioMajesty Series JCA-BM2250, Japan Electron Optics Laboratory Ltd., Tokyo, Japan). BCS was assessed using a five-point scale [8].

The values are expressed as mean \pm standard deviation (SD). Statistical significance was determined using the Kruskal-Wallis for comparison of BCS, lipoprotein fractions and serum biochemistry analysis with GraphPad Prism 6 software (GraphPad Software, Inc., San Diego, CA, USA). Differences were considered statistically significant at $P<0.05$. 


\section{RESULTS}

The changes in Total-C, HDL-C, and LDL-C level, and HDL-C/LDL-C (\%), HDL-C/Total-C (\%), and LDL-C/Total-C (\%) ratios in healthy dairy cows during the transition period are shown in Fig. 1. All lipoprotein profiles indicated significant changes during the transition period $(P<0.05)$. The Total-C and HDL-C levels decreased from $4 \mathrm{w}$ prepartum to calving, and thereafter increased (Fig. 1A, 1B). LDL-C decreased from $4 \mathrm{w}$ prepartum to $1 \mathrm{w}$ postpartum, and thereafter increased (Fig. 1C). The IDL-C and VLDL-C levels were too low to be measured. The HDL-C/LDL-C ratio increased from $4 \mathrm{w}$ prepartum to $2 \mathrm{w}$ postpartum, and thereafter decreased (Fig. 1D). HDL-C/Total-C increased from $4 \mathrm{w}$ prepartum to $2 \mathrm{w}$ postpartum, and thereafter decreased (Fig. 1E). LDL-C/Total-C decreased from $4 \mathrm{w}$ prepartum to $2 \mathrm{w}$ postpartum, and thereafter increased (Fig. 1F). The results of BCS and serum biochemistry analysis in healthy cows during the transition period are shown in Table 5.

The profiles of BCS, lipoprotein profiles and serum biochemistry of cows with 10 healthy (at calving and $1 \mathrm{w}$ postpartum) and fatty liver $(n=10)$ and milk fever $(n=6)$ group are shown in Table 6. Significant difference was observed in HDL-C between healthy cows (calving and $1 \mathrm{w}$ postpartum), and the fatty liver and milk fever group. Cows in the fatty liver and milk fever group had a lower mean HDL-C than the 10 healthy dairy cows at calving and $1 \mathrm{w}$ postpartum. The Total-C and LDL-C levels, and HDL-C/ LDL-C, HDL-C/Total-C (\%), and LDL-C/Total-C (\%) did not show any significant differences between the groups. The serum biochemistry results revealed that significant differences were observed in total bilirubin, aspartate aminotransferase, gammaglutamyltransferase, blood urea nitrogen, glucose, calcium, inorganic phosphorus, magnesium, phospholipid, and NEFA levels between the groups $(P<0.05)$.

A.

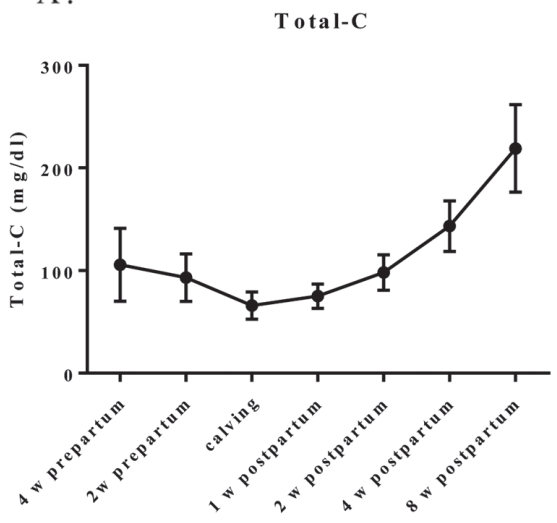

D.

H D L/L D L

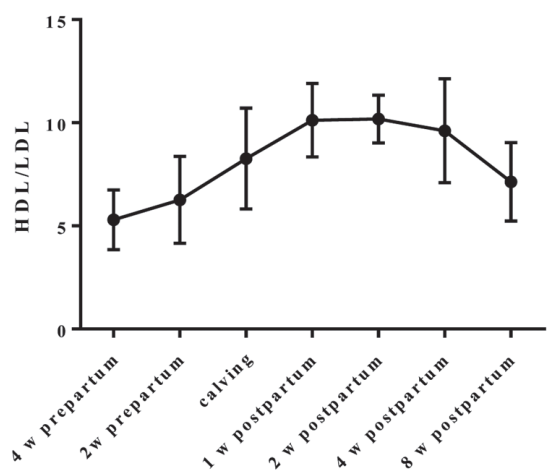

B.

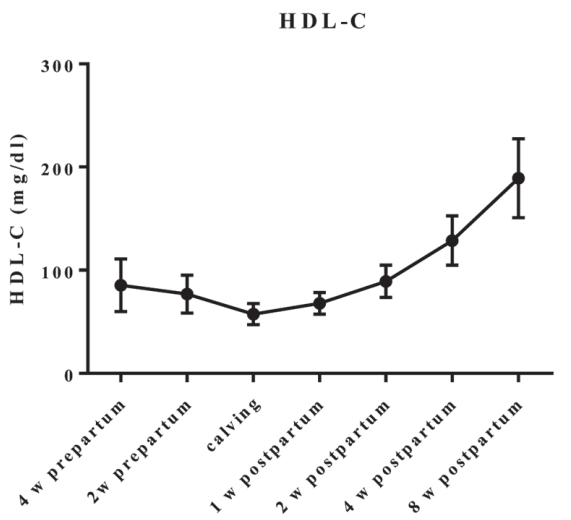

E.

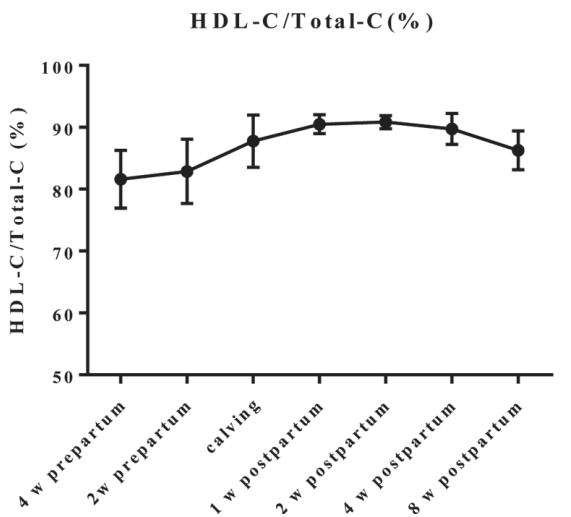

C.

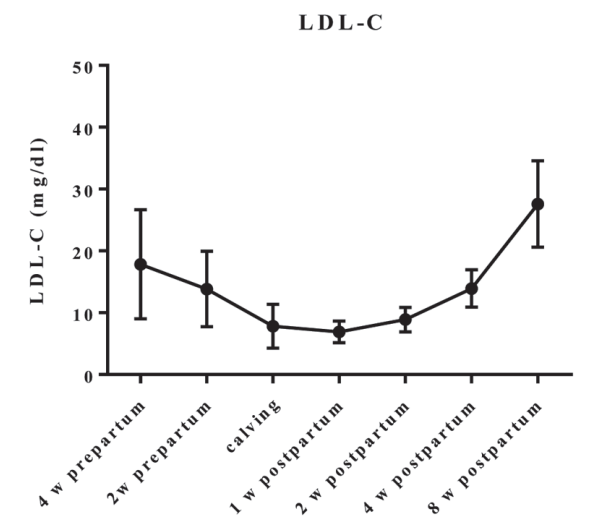

F.

L D L-C/T otal-C (\%)

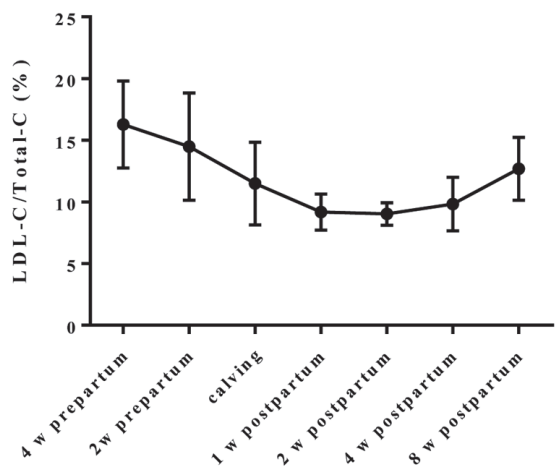

Fig. 1. Changes in lipoprotein profiles (A: total cholesterol, B: high-density lipoprotein (HDL) cholesterol, C: low-density lipoprotein (LDL) cholesterol, D: HDL cholesterol/LDL cholesterol, E: HDL cholesterol/total cholesterol, F: LDL cholesterol/total cholesterol) in 10 healthy dairy cows during the transition period (4 weeks (w) prepartum, $2 \mathrm{w}$ prepartum, calving, $1 \mathrm{w}$ postpartum, $2 \mathrm{w}$ postpartum, $4 \mathrm{w}$ postpartum, and $8 \mathrm{w}$ postpartum). Values are expressed as mean \pm standard deviation (SD). 
Table 5. Body condition score and serum biochemical analysis of 10 healthy dairy cows during the transitional period

\begin{tabular}{|c|c|c|c|c|c|c|c|c|}
\hline Blood biomarkers (unit) & $\begin{array}{c}4 \mathrm{w} \\
\text { prepartum }\end{array}$ & $\begin{array}{c}2 \mathrm{w} \\
\text { prepartum }\end{array}$ & Calving & $\begin{array}{c}1 \mathrm{~W} \\
\text { postpartum }\end{array}$ & $\begin{array}{c}2 \mathrm{~W} \\
\text { postpartum }\end{array}$ & $\begin{array}{c}4 \mathrm{w} \\
\text { postpartum }\end{array}$ & $\begin{array}{c}8 \mathrm{w} \\
\text { postpartum }\end{array}$ & $\begin{array}{c}\text { Kruskal-Wallis } \\
\text { test }\end{array}$ \\
\hline Body condition score & $3.28 \pm 0.36$ & $3.35 \pm 0.38$ & $3.28 \pm 0.30$ & $3.20 \pm 0.35$ & $3.13 \pm 0.38$ & $3.00 \pm 0.41$ & $2.90 \pm 0.38$ & 0.0654 \\
\hline Total protein $(\mathrm{g} / \mathrm{dl})$ & $7.5 \pm 0.8$ & $7.8 \pm 0.7$ & $6.6 \pm 0.6$ & $6.4 \pm 0.4$ & $7.1 \pm 0.5$ & $7.7 \pm 0.8$ & $7.9 \pm 0.4$ & $<0.0001$ \\
\hline $\operatorname{Albumin}(\mathrm{g} / \mathrm{dl})$ & $3.7 \pm 0.4$ & $3.9 \pm 0.7$ & $3.5 \pm 0.3$ & $3.3 \pm 0.2$ & $3.4 \pm 0.4$ & $3.4 \pm 0.3$ & $3.6 \pm 0.3$ & 0.0355 \\
\hline Total bilirubin $(\mathrm{mg} / \mathrm{dl})$ & $0.1 \pm 0.1$ & 0.1 & $0.2 \pm 0.1$ & $0.2 \pm 0.2$ & $0.2 \pm 0.1$ & $0.2 \pm 0.1$ & $0.2 \pm 0.1$ & 0.0226 \\
\hline aspartate aminotransferase (IU/1) & $65.5 \pm 17.3$ & $70.3 \pm 11.3$ & $83.0 \pm 28.3$ & $96.1 \pm 20.1$ & $99.3 \pm 26.9$ & $85.2 \pm 13.9$ & $85.6 \pm 25.1$ & 0.0010 \\
\hline Gamma-glutamyltransferase (IU/1) & $25.8 \pm 6.1$ & $24.5 \pm 3.8$ & $22.4 \pm 4.9$ & $21.5 \pm 6.1$ & $25.8 \pm 9.3$ & $26.8 \pm 7.7$ & $31.7 \pm 11.9$ & 0.0979 \\
\hline Blood urea nitrogen $(\mathrm{mg} / \mathrm{dl})$ & $13.1 \pm 2.7$ & $13.6 \pm 3.7$ & $11.3 \pm 2.8$ & $8.9 \pm 2.9$ & $9.4 \pm 2.4$ & $11.8 \pm 2.1$ & $14.7 \pm 3.8$ & 0.0018 \\
\hline Creatinine $(\mathrm{mg} / \mathrm{dl})$ & $1.0 \pm 0.2$ & $1.1 \pm 0.3$ & $1.1 \pm 0.3$ & $1.0 \pm 0.2$ & $0.9 \pm 0.2$ & $0.7 \pm 0.1$ & $0.7 \pm 0.1$ & 0.0004 \\
\hline Glucose (mg/dl) & $71.1 \pm 13.0$ & $80.5 \pm 15.1$ & $99.8 \pm 33.9$ & $48.4 \pm 13.5$ & $48.5 \pm 13.5$ & $48.4 \pm 12.2$ & $57.3 \pm 6.8$ & $<0.0001$ \\
\hline Calcium (mg/dl) & $10.2 \pm 1.1$ & $10.8 \pm 1.1$ & $8.6 \pm 1.1$ & $9.1 \pm 1.2$ & $9.8 \pm 0.7$ & $9.7 \pm 0.5$ & $9.6 \pm 0.6$ & 0.0014 \\
\hline Inorganic phosphorus (mg/dl) & $6.5 \pm 1.0$ & $7.2 \pm 1.4$ & $4.1 \pm 1.0$ & $5.9 \pm 1.8$ & $6.3 \pm 1.6$ & $6.1 \pm 0.9$ & $5.6 \pm 0.7$ & 0.0002 \\
\hline Magnesium (mg/dl) & $2.4 \pm 0.4$ & $2.6 \pm 0.5$ & $2.5 \pm 0.6$ & $2.0 \pm 0.2$ & $2.4 \pm 0.5$ & $2.4 \pm 0.2$ & $2.4 \pm 0.1$ & 0.0288 \\
\hline Triglyceride (mg/dl) & $18.1 \pm 5.9$ & $20.8 \pm 8.4$ & ND & ND & ND & ND & $\mathrm{ND}$ & - \\
\hline Phospholipid (mg/dl) & $113.6 \pm 30.5$ & $111.0 \pm 21.0$ & $66.4 \pm 16.8$ & $84.8 \pm 11.5$ & $111.1 \pm 17.8$ & $157.1 \pm 27.4$ & $214.9 \pm 37.7$ & $<0.0001$ \\
\hline
\end{tabular}

Values are presented as mean \pm standard deviation. ND means not detected; Values of a number of samples were analyzed as $<5 \mathrm{mg} / \mathrm{dl}$.

Table 6. Comparison of lipoprotein fractions and biochemical parameters between healthy cows (at calving and 1 week postpartum) and cows with transitional disorder

\begin{tabular}{lccccc}
\hline \multicolumn{1}{c}{ Blood biomarkers (units) } & $\begin{array}{c}\text { healthy cows at } \\
\text { calving }(\mathrm{n}=10)\end{array}$ & $\begin{array}{c}\text { healthy cows 1 w } \\
\text { postpartum }(\mathrm{n}=10)\end{array}$ & $\begin{array}{c}\text { cows with fatty } \\
\text { liver }(\mathrm{n}=10)\end{array}$ & $\begin{array}{c}\text { cows with milk } \\
\text { fever }(\mathrm{n}=6)\end{array}$ & $\begin{array}{c}\text { Kuruskul-Wallis } \\
\text { test }\end{array}$ \\
\hline Duration from calving & 0 & 7 & $4.4 \pm 3.0$ & $1.3 \pm 1.9$ & - \\
Body condition score & $3.28 \pm 0.30$ & $3.20 \pm 0.35$ & $3.43 \pm 0.54$ & $3.29 \pm 0.29$ & 0.7840 \\
Total-cholesterol (mg/dl) & $65.8 \pm 13.3$ & $75.0 \pm 11.9$ & $62.3 \pm 9.9$ & $61.5 \pm 17.2$ & 0.1431 \\
HDL-cholesterol (mg/dl) & $57.5 \pm 10.3$ & $67.9 \pm 10.5$ & $55.2 \pm 8.8$ & $53.3 \pm 13.8$ & 0.0446 \\
LDL-cholesterol (mg/dl) & $7.8 \pm 3.5$ & $6.9 \pm 1.7$ & $6.8 \pm 2.2$ & $7.6 \pm 4.1$ & 0.9715 \\
HDL/LDL (ratio) & $8.3 \pm 2.4$ & $10.1 \pm 1.8$ & $8.8 \pm 2.8$ & $8.8 \pm 4.4$ & 0.3794 \\
HDL-cholesterol (\%) & $87.8 \pm 4.2$ & $90.5 \pm 1.5$ & $88.7 \pm 3.8$ & $87.2 \pm 5.5$ & 0.4019 \\
LDL-cholesterol (\%) & $11.5 \pm 3.3$ & $9.2 \pm 1.5$ & $10.9 \pm 2.9$ & $11.7 \pm 4.4$ & 0.3355 \\
Total protein (g/dl) & $6.6 \pm 0.6$ & $6.4 \pm 0.4$ & $6.8 \pm 0.5$ & $6.9 \pm 0.1$ & 0.1845 \\
Albumin (g/dl) & $3.5 \pm 0.3$ & $3.3 \pm 0.2$ & $3.5 \pm 0.4$ & $3.5 \pm 0.3$ & 0.2176 \\
Total bilirubin (mg/dl) & $0.2 \pm 0.1$ & $0.2 \pm 0.2$ & $1.1 \pm 0.3$ & $0.4 \pm 0.3$ & $<0.0001$ \\
Aspartate aminotransferase (IU/l) & $83.0 \pm 28.3$ & $96.1 \pm 20.1$ & $270.9 \pm 206.0$ & $80.0 \pm 18.2$ & 0.0005 \\
Gamma-glutamyltransferase (IU/l) & $22.4 \pm 4.9$ & $21.5 \pm 6.1$ & $37.5 \pm 12.3$ & $25.0 \pm 3.8$ & 0.0011 \\
Blood urea nitrogen (mg/dl) & $11.3 \pm 2.8$ & $8.9 \pm 2.9$ & $13.3 \pm 3.6$ & $13.8 \pm 2.1$ & 0.0116 \\
Creatinine (mg/dl) & $1.1 \pm 0.3$ & $1.0 \pm 0.2$ & $1.0 \pm 0.2$ & $1.1 \pm 0.3$ & 0.6987 \\
Glucose (mg/dl) & $99.8 \pm 33.9$ & $48.4 \pm 13.5$ & $43.7 \pm 20.5$ & $72.2 \pm 60.3$ & 0.0012 \\
Calcium (mg/dl) & $8.6 \pm 1.1$ & $9.1 \pm 1.2$ & $8.5 \pm 1.0$ & $5.5 \pm 1.0$ & 0.0022 \\
Inorganic phosphorus (mg/dl) & $4.1 \pm 1.0$ & $5.9 \pm 1.8$ & $5.4 \pm 2.1$ & $2.4 \pm 1.4$ & 0.0021 \\
Magnesium (mg/dl) & $2.5 \pm 0.6$ & $2.0 \pm 0.2$ & $1.9 \pm 0.4$ & $2.5 \pm 0.6$ & 0.0400 \\
Triglyceride (mg/dl) & $\mathrm{ND}$ & $\mathrm{ND}$ & $\mathrm{ND}$ & $\mathrm{ND}$ & - \\
Phospholipid (mg/dl) & $66.4 \pm 16.8$ & $84.8 \pm 11.5$ & $78.7 \pm 11.6$ & $61.0 \pm 13.1$ & 0.0089 \\
Non-esterified fatty acids ( $\mu \mathrm{EEQ} / \mathrm{l})$ & $530.6 \pm 293.4$ & $568.2 \pm 270.4$ & $1,476.0 \pm 366.5$ & $748.2 \pm 383.6$ & 0.0002 \\
\hline
\end{tabular}

Values are presented as means \pm standard deviation. ND means not detected; Values of all samples were analyzed as $<5 \mathrm{mg} / \mathrm{dl}$.

\section{DISCUSSION}

$\mathrm{HDL}-\mathrm{C}$ is the main lipoprotein for transporting cholesterol in cows [32]. In the present study, most cows had a HDL-C/Total-C ratio of $>80 \%$. Cows usually have an LDL-C/Total-C ratio of $<20 \%$. In the present study, the LDL-C/Total-C ratio in cows during the transition period was between 10 and $20 \%$. LDL is the end product of VLDL metabolism. VLDL-C, IDL-C, and chylomicrons were not detected using the AEX-HPLC method in the present study.

A preliminary study of the changes in the lipoprotein fraction during the transition period in the ten healthy dairy cows on the two farms was done. The Total-C, HDL-C, and LDL-C levels were low at $4 \mathrm{w}$ prepartum, with the lowest levels at calving or $1 \mathrm{w}$ postpartum and levels increased until $8 \mathrm{w}$ postpartum. A similar result has been reported previously [16, 17, 21, 31]. A decrease in the HDL-C level (as well as LDL-C) prepartum is due to a decrease in DMI because of fetal growth and due to the increased 
requirement for cholesterol for maternal steroid hormone production at the end of pregnancy [13, 30]. Maintaining HDL-C-rich lipoprotein profiles throughout the transition period limits the increase in NEFAs and ensures energy balance in dairy cows [22]. In human studies, HDL-C is a good indicator of hepatocellular function for patients with acute liver failure [19]. Although this has been suggested in dairy cows [22], the relationship between HDL-C during the transition period and hepatocellular function and energy balance in dairy cows should be studied further.

The lipoprotein profiles of the 10 cows with fatty liver, the six cows in the milk fever group, and the 10 healthy dairy cows (at calving and $1 \mathrm{w}$ postpartum) were compared to investigate the clinical significance of the lipoprotein profiles. Peripartum disease induces a decrease in apolipoprotein B-100 and A-I, comprising HDL-C, LDL-C, IDL-C, and VLDL-C [9, 24]. Furthermore, a decrease in serum lipoprotein in cows during the periparturient period is related to hepatic steatosis [20, 26]. In the present study, the cows with fatty liver and milk fever had a lower mean HDL-C level than healthy dairy cows at calving and $1 \mathrm{w}$ postpartum. Previous studies have suggested that cows with a serum HDL level of $>89 \%$ at dry-off could result in a better reproductive performance than lower HDL levels [5]. In the present study, cows with fatty liver (5/10) and milk fever (2/6) had a HDL-C/Total-C ratio of $>89 \%$. The ratio of HDL-C/Total-C is not a useful marker for differentiating healthy and cows with TCD. Furthermore, cows with fatty liver (9/10) and milk fever (5/6) had an HDL-C level of $<65 \mathrm{mg} / \mathrm{dl}$. Newman et al. [22] suggested that the ability of cows to produce adequate levels of HDL is a better indicator of liver function than TG level or LDL. Additionally, HDL is considered an anti-inflammatory lipoprotein in human study [27]. Whether a high HDL-C level also has a positive effect in dairy cows in order to prevent TCD during the transition period should be studied further. The occurrence of fatty liver is correlated with a negative energy balance and HDL-C might be a key factor in maintaining hepatic function and ameliorating pathophysiology of the disease. Since milk fever is more related to calcium adjustment in the dry period through feeding, decreased HDL-C might be related to onset of the disease (mean 1.3 days, relatively close to calving) (Table 6). Generally, the LDL-C level is reduced in cows with fatty liver syndrome [21]. However, we did not detect changes in LDL-C level between groups. In the future, lipoprotein profiles for each manifestation of fatty liver, milk fever, and displaced abomasum should be elucidated by increasing the number of cows in each category.

Some biochemical analysis results were different between the groups. Increased glutamic oxaloacetic transaminase and gammaglutamyltransferase activities, and total bilirubin and NEFA levels in cows with fatty liver might be related to hepatic cell damage and negative energy balance [11]. An increase in the glucose level in healthy cows at calving might be related to insulin resistance and delivery stress [6]. A decreased calcium level in the milk fever group is related to the pathophysiology of the disease.

Furthermore, the Total-C and TG levels $(<5 \mathrm{mg} / \mathrm{dl}$ in all samples) were not significantly different between the groups. HDL-C would be a more useful lipid marker for evaluating hepatic cholesterol production and energy balance than lipid markers (Total-C and TGs).

In conclusion, in the present study, a preliminary study of the changes in lipoprotein profiles was determined using AEX-HPLC in healthy dairy cows on two dairy farm during the transition period. In the future, a larger trial would be appropriate to obtain reference values for evaluating lipoprotein profiles using AEX-HPLC. Furthermore, HDL-C might be a useful lipid indicator for differentiating healthy cows and cows with fatty liver and milk fever. In the future, changes in diet and/or rearing management to maintain higher HDL-C levels in dairy cows during the transition period should be investigated.

POTENTIAL CONFLICTS OF INTEREST. The authors have nothing to disclose.

\section{REFERENCES}

1. Abuelo, A., Hernández, J., Benedito, J. L. and Castillo, C. 2016. Association of oxidative status and insulin sensitivity in periparturient dairy cattle: an observational study. J. Anim. Physiol. Anim. Nutr. (Berl.) 100: 279-286. [Medline] [CrossRef]

2. Bauchart, D. 1993. Lipid absorption and transport in ruminants. J. Dairy Sci. 76: 3864-3881. [Medline] [CrossRef]

3. Bobe, G., Young, J. W. and Beitz, D. C. 2004. Invited review: pathology, etiology, prevention, and treatment of fatty liver in dairy cows. J. Dairy Sci. 87: 3105-3124. [Medline] [CrossRef]

4. Chapinal, N., Leblanc, S. J., Carson, M. E., Leslie, K. E., Godden, S., Capel, M., Santos, J. E., Overton, M. W. and Duffield, T. F. 2012. Herd-level association of serum metabolites in the transition period with disease, milk production, and early lactation reproductive performance. J. Dairy Sci. 95: 5676-5682. [Medline] [CrossRef]

5. Crociati, M., Sylla, L., Floridi, C., Comin, A., Fruganti, G., Monaci, M. and Stradaioli, G. 2017. Influence of lipoproteins at dry-off on metabolism of dairy cows during transition period and on postpartum reproductive outcomes. Theriogenology 94: 31-36. [Medline] [CrossRef]

6. De Koster, J. D. and Opsomer, G. 2013. Insulin resistance in dairy cows. Vet. Clin. North Am. Food Anim. Pract. 29: 299-322. [Medline] [CrossRef]

7. Drackley, J. K. 1999. ADSA Foundation Scholar Award. Biology of dairy cows during the transition period: the final frontier? J. Dairy Sci. 82: 2259-2273. [Medline] [CrossRef]

8. Ferguson, J. D., Galligan, D. T. and Thomsen, N. 1994. Principal descriptors of body condition score in Holstein cows. J. Dairy Sci. 77: $2695-2703$. [Medline] [CrossRef]

9. Geishauser, T. 1995. Abomasal displacement in the bovine--a review on character, occurrence, aetiology and pathogenesis. Zentralbl. Veterinärmed. A 42: 229-251. [Medline] [CrossRef]

10. Goff, J. P. and Horst, R. L. 1997. Physiological changes at parturition and their relationship to metabolic disorders. J. Dairy Sci. 80: $1260-1268$. [Medline] [CrossRef]

11. González, F. D., Muiño, R., Pereira, V., Campos, R. and Benedito, J. L. 2011. Relationship among blood indicators of lipomobilization and hepatic function during early lactation in high-yielding dairy cows. J. Vet. Sci. 12: 251-255. [Medline] [CrossRef] 
12. Gross, J. J., Kessler, E. C., Albrecht, C. and Bruckmaier, R. M. 2015. Response of the cholesterol metabolism to a negative energy balance in dairy cows depends on the lactational stage. PLoS One 10: e0121956. [Medline] [CrossRef]

13. Grummer, R. R. 1993. Etiology of lipid-related metabolic disorders in periparturient dairy cows. J. Dairy Sci. 76: 3882-3896. [Medline] [CrossRef]

14. Grummer, R. R. 1995. Impact of changes in organic nutrient metabolism on feeding the transition dairy cow. J. Anim. Sci. 73: 2820-2833. [Medline] [CrossRef]

15. Ingvartsen, K. L. and Andersen, J. B. 2000. Integration of metabolism and intake regulation: a review focusing on periparturient animals. J. Dairy Sci. 83: 1573-1597. [Medline] [CrossRef]

16. Kessler, E. C., Gross, J. J., Bruckmaier, R. M. and Albrecht, C. 2014. Cholesterol metabolism, transport, and hepatic regulation in dairy cows during transition and early lactation. J. Dairy Sci. 97: 5481-5490. [Medline] [CrossRef]

17. Kurpińska, A. K., Jarosz, A., Ożgo, M. and Skrzypczak, W. F. 2015. Changes in lipid metabolism during last month of pregnancy and first two months of lactation in primiparous cows - analysis of apolipoprotein expression pattern and changes in concentration of total cholesterol, HDL, LDL, triglycerides. Pol. J. Vet. Sci. 18: 291-298. [Medline] [CrossRef]

18. Manita, D., Hirowatari, Y. and Yoshida, H. 2015. A rapid anion-exchange chromatography for measurement of cholesterol concentrations in five lipoprotein classes and estimation of lipoprotein profiles in male volunteers without overt diseases. Ann. Clin. Biochem. 52: 638-646. [Medline] [CrossRef]

19. Manka, P., Olliges, V., Bechmann, L. P., Schlattjan, M., Jochum, C., Treckmann, J. W., Saner, F. H., Gerken, G., Syn, W. K. and Canbay, A. 2014. Low levels of blood lipids are associated with etiology and lethal outcome in acute liver failure. PLoS One 9: e102351. [Medline] [CrossRef]

20. Mazur, A., Ayrault-Jarrier, M., Chilliard, Y. and Rayssiguier, Y. 1992. Lipoprotein metabolism in fatty liver dairy cows. Diabete Metab. 18 145-149. [Medline]

21. Miyamoto, T., Sugiyama, Y., Suzuki, J., Oohashi, T. and Takahashi, Y. 2006. Determination of bovine serum low-density lipoprotein cholesterol using the N-geneous method. Vet. Res. Commun. 30: 467-474. [Medline] [CrossRef]

22. Newman, A., Mann, S., Nydam, D. V., Overton, T. R. and Behling-Kelly, E. 2016. Impact of dietary plane of energy during the dry period on lipoprotein parameters in the transition period in dairy cattle. J. Anim. Physiol. Anim. Nutr. (Berl.) 100: 118-126. [Medline] [CrossRef]

23. Oda, H., Mori, A., Hirowatari, Y., Takoura, T., Manita, D., Takahashi, T., Shono, S., Onozawa, E., Mizutani, H., Miki, Y., Itabashi, Y. and Sako, T. 2017. Cholesterol concentrations in lipoprotein fractions separated by anion-exchange-high-performance liquid chromatography in healthy dogs and dogs with hypercholesterolemia. Res. Vet. Sci. 114: 163-169. [Medline] [CrossRef]

24. Oikawa, S., Katoh, N., Kawawa, F. and Ono, Y. 1997. Decreased serum apolipoprotein B-100 and A-I concentrations in cows with ketosis and left displacement of the abomasum. Am. J. Vet. Res. 58: 121-125. [Medline]

25. Radcliff, R. P., McCormack, B. L., Crooker, B. A. and Lucy, M. C. 2003. Plasma hormones and expression of growth hormone receptor and insulinlike growth factor-I mRNA in hepatic tissue of periparturient dairy cows. J. Dairy Sci. 86: 3920-3926. [Medline] [CrossRef]

26. Rayssiguier, Y., Mazur, A., Gueux, E., Reid, I. M. and Roberts, C. J. 1988. Plasma lipoproteins and fatty liver in dairy cows. Res. Vet. Sci. 45: 389-393. [Medline] [CrossRef]

27. Säemann, M. D., Poglitsch, M., Kopecky, C., Haidinger, M., Hörl, W. H. and Weichhart, T. 2010. The versatility of HDL: a crucial antiinflammatory regulator. Eur. J. Clin. Invest. 40: 1131-1143. [Medline] [CrossRef]

28. Sordillo, L. M. and Aitken, S. L. 2009. Impact of oxidative stress on the health and immune function of dairy cattle. Vet. Immunol. Immunopathol. 128: 104-109. [Medline] [CrossRef]

29. Takahashi, T., Mori, A., Hirowatari, Y., Oda, H., Takoura, T., Manita, D., Mizutani, H., Miki, Y., Itabashi, Y. and Sako, T. 2017. Analysis of cholesterol lipoprotein separations in Holstein dairy cattle by anion-exchange high-performance liquid chromatography. J. Pet Anim. Nutr. 20: $30-38$.

30. Turk, R. 2009: The role of HDL-associated enzymes in bovine reproduction., pp. 1-17. In: HDL and LDL Cholesterol: Physiology and Clinical Significance (Pagano, S. I. and Strait, B. N. eds.), Nova Science Publishers Inc., New York.

31. Turk, R., Podpečan, O., Mrkun, J., Flegar-Meštrić, Z., Perkov, S. and Zrimšek, P. 2015. The effect of seasonal thermal stress on lipid mobilisation, antioxidant status and reproductive performance in dairy cows. Reprod. Domest. Anim. 50: 595-603. [Medline] [CrossRef]

32. van Dijk, S. and Wensing, T. 1989. Comparison of the lipoprotein pattern of the horse, the pony and the lactating and non-lactating cow obtained by a combination of an ultracentrifugation and a precipitation technique. Comp. Biochem. Physiol. B 94: 735-738. [Medline] [CrossRef] 